\section{APPRENTICE SURVEYORS}

Names of 115 librarians who would welcome opportunities to serve as apprentice surveyors have been collected by the ACRL Committee on Library Surveys. These are persons who wrote in response to an invitation from the Committee in the November 1968 issue of CURL News; they are located in 33 states and 2 Canadian provinces, and their interests and special qualifications are as diverse as the problems encountered in surveys of college and university libraries.

Collection of the names was the first step in an effort by the Committee to increase the number of well qualified surveyors by providing opportunities for experience. The Committee recommends that each survey team include an apprentice member, and invites directors of surveys to draw upon its roster. It will welcome opportunities to suggest names of prospective apprentices who seem to be particularly well prepared to contribute to any survey that is being planned. Requests for information should be addressed to Edwin E. Williams, Chairman, ACRL Committee on Library Surveys, Widener Library 183, Harvard University, Cambridge, Mass. 02138.

\section{ACRL/JCLS PRECONFERENCE}

\footnotetext{
"New Strategies for Learning: the Impact of Instructional Technology Upon the Junior College" will be the theme of a preconference sponsored by the American Association of Junior Colleges and the Association of College and Research Libraries at Atlantic City from June 19-21. Planned to stimulate dialogue between administrators, faculty, librarians and media specialists; the two days of sessions will include demonstrations, concurrent workshops, and contact with resource persons. Major presentations will be made by Bill J. Priest, chancellor, Dallas County Junior College District, Dallas, Texas; Gabriel Ofiesh, chairman, department of educational technology, Catholic University, Washington, D.C.; James Zigerall, Dean, TV College, Chicago City College; and Carol Zion, assistant to the vice-president, Miami Dade Junior College.

Maurice B. Mitchell, chancellor of the University of Denver and former president and editorial director of Encyclopaedia Britannica, will speak at the banquet to be held in connection with the preconference on Friday, June 20. Attendance is limited to 500 persons, and the registration fee, including three meals, is $\$ 50$. Reservation forms and information may be requested from the Association of College and Research Libraries, American Library As-
}

sociation, 50 East Huron Street, Chicago, Illinois 60611 .

\section{SUBJECT ANALYSIS OF LIBRARY MATERIALS}

An American Library Association Preconference Institute sponsored by Information Science and Automation Division, Resources and Technical Services Division's Cataloging and Classification Section, and Columbia University, June 19-21, Traymore Hotel, Atlantic City.

A 1969 updating of the Conference on Subject Analysis of Library Materials, Columbia University, 1952, to provide an interpretive overview of the state of the art of subject analysis, especially as it has developed in the last twenty years.

Registration blanks will be mailed to all ALA members. Registrations to the limit of 700 will be accepted with the registration fee of $\$ 35.00$ on a first-come, first-served basis. The fee includes a Banquet ticket, coffee service during the meeting breaks, and one copy of the proceedings to be published by Columbia University, School of Library Service.

\section{INSIDE THE DLP . .

$$
\text { (Continued from page 105) }
$$

\section{Applicants}

Branches may now apply for Supplemental and Special Purpose Types A and B grants, as well as Basic grants, through the parent institution. Beginning in 1969-70, new institutions may apply for Basic grants one year before they open.

These five paragraphs are necessarily brief and sketchy. The new program documents for 1968-69 will provide a comprehensive treatment of the new Title Il-A regulations.

You will note on the last two pages of the Instructions the addresses and phone numbers of our nine Regional Library Service program officers. Call the one in your region if you need further assistance and information about the Title II-A programs.

\section{PERSONNEL . . .}

$$
\text { (Continued from page 132) }
$$

association with the North Texas State University library.

Mrs. Natalie NotKin has retired after twenty years of service with the University of Washington libraries.

Mrs. Marion Stanton has retired after eleven years of service with the University of Washington libraries.

NAOMI StreE', a member of the staff of the New York Public library's art and architecture division for the past eighteen years, retired on December 31, 1968. 